Albrni Abdarahman R A

\title{
NEGOTIATION: STRATEGIC AND TACTICAL ADMISSION
}

In the article it is definite that the negotiations are the process of interaction of several interdependent parties whose purpose is to achieve their own interests. It is Proved that the main achievement in the negotiations is the adoption of appropriate decisions. It is Noted that the solution of the problem is influenced by: relations between the parties; The possibility and reality of the parties 'claims; Personal interests or interests of the team; Effectiveness of intra-group discussions in finding consensus.

It has been Revealed that when entering the negotiation process, its participants use different strategies of their management, and the choice of a strategy depends on: the conditions/structure in which negotiations are conducted; Aspiration of the parties to realize each other's interests (ability to listen and be heard); Comprehension and realization of success of negotiations by their participants.

It is Proved that for skillful negotiations it is necessary to have a strategy which is realized in tactics. Communication Tactics is the use of speaking speech skills to build a dialogue within the framework of the implemented strategist. It is Noted that this tactic and the ability to choose in a particular situation psychologically effective techniques and skillfully apply them to this interlocutor.

It has been Revealed that the purpose of negotiations is to develop a correct and proper attitude to the interlocutor by solving the following tasks: establishing contact with a partner; Organization and formation of pleasant atmosphere of communication; $A$ manifestation of interest in mutual proposals; Establishing the wishes of the other party; Providing a "soft" transition to dialogue.

Key words: Negotiations, negotiation process, negotiation strategy, tactics, tactical techniques, negotiation technique, conflicts.

УДК 32.001.(075.8)

\section{ІНСТИТУТ ПРЕЗИДЕНТСТВА ЯК СУБ'ЄКТ КОНЦЕПТУАЛЬНОӤ ВЛАДИ В ДЕМОКРАТИЧНИХ ПОЛІТИЧНИХ СИСТЕМАХ}

У статті розглядаються особливості моделі інституту президентства як досвід інститутів США. Проаналізовано поняття: політика президента, вирішення політичних конфліктів. Розглянуто політичні передумови та чинники політичних стратеаій президенціалізму. взаємозв'язок інституту президента як суб'єкта концептуальної влади і демократичної політичної системи, як її об'єкта. Показується, що реальна модель політичної системи містить олігархічний $i$ антиолігархічний компоненти, кожний з яких може стати переважним. Концептуальне регулювання політичної системи, збереження їі демократичної визначеності, є найважливішою задачею президентської влади. Використання теоретичних моделей Д. Істона, теорії потреб А. Маслоу і теорії соціальної мобільності П. Сорокіна дозволило виявити статичний і динамічний параметри політичної системи, оптимізація яких дає можливість підтримувати еволюційний характер політичного розвитку.

Ключові слова: політика, політична консолідація, концептуальна влада, інститут президентства, концепція державного ладу, демократична політична система.

Вступ. Посада президента є основним, але лише одним зі складених елементів інституту президентства. Для того щоб цей інститут зайняв належне місце в політичній системі, необхідна ефективна конституційна база президентства і широка суспільно-політична підтримка президентської влади. В Основному законі та інших правових нормах мають бути максимально чітко і повно визначений статус глави держави, його повноваження i межі цих повноважень. Набуття президентською владою інституціонального характеру неможливе без ретельної правової регламентації взаємин президента 3 урядом, парламентом, місцевими органами влади. Iнститут президентства припускає також наявність налагодженої організаційно-управлінської структури президентського апарату, ефективної процедури прийняття рішень, морально-етичних норм для тих, хто займає вищу офріційну посаду в державі.

Залишаючись у рамках своїх конституційних повноважень, президент може активно використовувати весь потенціал своєї посади й ефективно вирішувати проблеми суспільного розвитку. Досвід інституту президентства і правові норми, що виявили свою доцільність у практиці, безсумнівно, корисні в процесі формування нової політичної системи в Україні.

Складність вирішення даної проблеми полягає в тому, що незалежно від цілеспрямування політичних акторів, що тлумачать про демократію, в будь-якому суспільстві з різною потужністю, але одночасно діють декілька альтернативних концепцій демократії. У той же час, юридично кодифікована і панує якась одна з них. Саме тому політична влада звичайно вимушена діяти антидемократичним чином щодо альтернативної концепції. Інститути державної влади завдяки стійкості, мобільності та ресурсоємності можуть підтримувати і насаджувати навіть ті норми і цілі, які не цілком відповідають інтересам суспільства, як цілісності, або навпаки - інтереси окремих, зазвичай найбільш активних індивідуумів і соціальних груп не враховуються та навіть при- носяться в жертву цілому. Виникає значний дисбаланс інтересів, що загрожує існуванню демократичного суспільного ладу. Отже, виникає завдання вироблення об'єктивних показників, якими має керуватися глава держави, щоб оцінювати сприятливі або несприятливі тенденції в політичній системі.

Мета статті та завдання. Метою статті є здійснення теоретико-методологічного аналізу сутності інституту президентства як суб'єкта концептуальної влади в демократичних політичних системах, виявити структуру концептуальної влади, її роль та місце у політичній системі суспільства, виявити тенденції та проаналізувати роль процесів олігархізації у функціонуванні демократичних політичних систем, розкрити концептуальні функції інституту президентства у західних демократичних політичних системах.

Виклад основного матеріалу. Дослідження президентської влади здійснюється за аспектами: конституційно-правовим, визначаючи місце і роль інституту президента в системі конституційного права (В.Шаповал, Ю. Тодика та ін.); повноваження президента в системі інститутів державної влади (Ф. Рудич, В. Шаповал, Г. Щедрова); історико-аналітичним (В. Ярошенко та ін.); електорального (А. Білоус, К. Ващенко та ін.). Таким чином, президентська влада досліджується тільки в межах ідеальної моделі політичної системи. Тим часом, в умовах демократичної трансформації посттоталітарного соціуму, рамки об'єкта повинні бути істотно розширені. Невірний вибір моделі державного ладу знижує ефективність політичного управління і загрожує демократії. Тут виникає задача вироблення надійних критеріїв політичного управління, що зв'язують реальні потреби суспільства з обраною моделлю конституційного устрою.

Основи конституційного ладу частини демократичних систем $€$ втіленням ідей цілої низки мислителів: А. Гамільтона, Т. Джеффферсона, Дж. Мілля, Ш.Л. Монтеск'є, М. Фрідмана. Вони виглядають як єдність лівого 
політичного курсу, основним елементом $€$ демократія, та правої економічної лінії, основною складовою є підтримка приватної власності, ринку, свободи торгівлі. Цю концепцію демократії і політичного управління визначають як олігархічну, тому що в її основі $€$ індивідуальний матеріальний інтерес [1, с.9].

Група антиолігархічних доктрин розроблялася Ж. Боденом, Ж.-Ж. Руссо, А. Гамільтоном. Загальний зміст їхніх ідей полягає в тім, що жорсткий поділ людей на еліту і масу має бути замінено на основі загальних базових інтересів. Якщо соціального компромісу домогтися не вдається, фундаментом державного ладу можуть стати радикальні антиолігархічні концепції Т. Кампанелли, Т. Мора, Р.Оуена, А. Сен-Симона, Ж.-Ж. Руссо [2, с.7].

Найважливіший аспект діяльності гаранта демократичності державного ладу полягає в забезпеченні балансу між олігархічними й антиолігархічними інтересами політичних агентів.

Отже, в галузі вивчення інституту президентства існують вади: задача адаптації обраної демократичної моделі державно-політичного устрою країни (конституційного ладу) до мінливих суспільних потреб і виявлення місця і ролі інституту президентства в цьому процесі.

За умов системної кризи, посилення ролі президента як голови держави $є$ необхідною умовою збереження цілісності політичної системи. Якщо політична система має демократичний характер, то критерій ефективності авторитарної діяльності президента - наявність балансу між олігархічною й антиолігархічною активністю всіх політичних агентів, якщо припиняються підстави для посилення централізму, ступінь авторитарності повинен знизитися. Мобілізаційний і екстрактивний ресурси суспільства можуть бути ефективно використані лише за умови, що політик врахує якість "людського матеріалу", потребу у відчутті власної гідності людини, а також переважного типу політичної участі. У стабільній фазі існування системи, інститут президента (правовий) та інститут президентства (політичний) збігаються. Досвід західних (західниких, ліберально-демократичних) політичних систем свідчить, що функція підтримки демократичної моделі політичної системи є обов'язком президента. При цьому президент відіграє роль або глави виконавчої влади (політичного менеджера вищого рангу), або формального глави держави, або ці функції поєднує [3, с.21].

За умов політичної кризи президент уживає заходів до збереження демократичного ладу суспільства. Комплекс цих заходів включає функцію підтримки демократичного характеру політичної системи.

В контексті європейської республіканської практики відбувався процес формування виконавчої влади в США. На першому етапі американської державності не тільки законодавча, але і виконавча влада були зосереджені в одному представницькому органі - Континентальному Конгресі. Одноособового глави держави в ту пору не існувало, а Конгрес вибирав з числа своїх членів президента, функції якого обмежувалися лише головуванням на засіданнях.

Досить швидка більшість політичних діячів молодої американської республіки дійшли висновку про неефективність діяльності Конгресу по виконанню законів і про необхідність поділу законодавчої і виконавчої влади. При цьому делегати Конституційного конвенту зібралися в 1787 р. у Філадельфії для прийняття федеральної Конституції США, зробили історичний вибір між монархією і республікою. Більшість американців, тільки що покінчивши з пануванням британської монархії, були рішуче налаштовані проти створення в себе вищої ви- конавчої влади в особі монарха, нехай навіть з обмеженими повноваженнями. Після дебатів серед творців американської Конституції взяло гору уявлення, що вища виконавча влада має бути єдиною, тобто зосередитися в руках одного, а не декількох посадових осіб. Таким чином, у побудові федеральної виконавчої влади США затвердився принцип єдиноначальності.

США стали першою країною у світі, де виникла посада президента, що об'єднала в одній особі главу держави і главу уряду. Крім того, саме в США зародився інститут президентства як один 3 найважливіших інститутів політичної системи. На відміну від інших держав того часу, де виконавча влада повсюдно мала монархічний, спадкоємний характер, у США главу держави стали обирати в ході загальних виборів.

Стівен Гровер Клівленд (англ. Stephen Grover Cleveland, першим ім'ям не користувався) (1837-1908) перше президентство, 22-й і потім 24-й президент США. Президент США, який обирався на 2 терміни з чотирирічною перервою (1885-1889, 1893-1897) [4, с.12].

3 початку політичної діяльності К. Клівленд зблизився 3 Демократичною партією. У 1865 намагався бути обраним на місце прокурора, але програв другу, республіканцю Лаймену К. Бассу. Уже будучи адвокатом, Гровер Клівленд був обраний шерифом одного з округів штату Нью-Йорк. У 1870-х роках міська влада у Буффало ставала корумпованішою. Коли республіканці висунули кандидатів з сумнівною репутацією, демократи побачили можливість отримати голоси за чесного кандидата. Клівленд був обраний мером Буффало та вступив на посаду 2 січня 1882 р. Клівленд став відомим, дякуючи боротьбі з корупцією за межами Буффало. У 1870 з підтримкою друга Оскара Фолсома, Клівленд був обраним на пост шерифра округа Ері на посаду 1 січня 1871. Ця робота була більш примітивною, ніж адвокатська діяльність, але давала стабільний і високий заробіток і залишала більше вільного часу для насолоди життям. На цій посаді Клівленду доводилося виконувати і вкрай неприємні обов'язки: він кілька разів особисто виконував вироки засудженим до смертної кари через повішення. У нього була можливість доручити це своєму заступнику, заплативши йому 10 доларів, але він нею не скористався. Через участь у стратах політичні супротивники надалі називали Клівленда "Катом з Буффрало". У зв'язку зі зростаючою репутацією Клівленда, посадові особи демократичної партії розглядали Г. Клівленда як можливого кандидата на посаду губернатора штату Нью-Йорк. Репутація чесного прихильника реформ, який розкриває факти корупції і безгосподарності й у такий спосіб зберігає гроші платників податків, зробила його кандидатом від демократичної партії на майбутні вибори губернатора Нью-Йорка.

На виборах Г. Клівленд отримав 535318 голосів проти 342464 голоси за республіканця Чарлза Дж. Фолгера. У перші два місяці на посту губернатора Клівленд наклав 8 вето на рішення палат Нью-Йорку, бо був проти зайвих, на його думку, витрат. Він не побоявся виступити проти корумпованого панування Темені Хол та штабу демократичної партії в Нью-Йорку. Прямий та чесний підхід до справ Клівленда дав йому народну підтримку, але також неприязнь окремих фракцій власної партії, наприклад, організації Таммані Хол у місті Нью-Йорк. 3 іншого боку, Теодор Рузвельт та інші республіканці-реформісти надали підтримку Г. Клівленду у проведенні законів з реформування муніципальної влади. У 1896 р. повинні були відбутися чергові президентські вибори.

Прихід на посаду глави держави. Г. Клівленда двічі обирали главою держави 3 перервою між термінами 
президентства. Вперше в історії США обраний у 18851889 р. двадцять другим президентом США, Г. Клівленд був змушений пропустити наступні чотири роки через перемогу в чергових виборах іншого кандидата. Однак у 1893-1897 р. він знову очолює країну і стає 24 Президентом США [5, с.7].

Наприкінці 60-х рр. Г. Клівленд став членом Демократичної партії і як її представник брав участь у виборах шерифра округу Ері. Одержавши перемогу, він у 1871-1873 р. підтримував за допомогою поліції правопорядок, допомагав судовим приставам, керував в'язницею і боровся зі злочинністю (до речі, особисто здійснив кілька смертних вироків).

Після закінчення служби Г. Клівленд повернувся додому до м. Буфффало і разом із двома друзями відкрив адвокатський офіс. У ньому він працював вісім років, не забуваючи при цьому пропагувати серед населення програму і політичний курс Демократичної партії. Особливу активність виявляв під час проведення трьох президентських кампаній, привселюдно підтримуючи кандидатів-демократів.

Однак його зусилля на федеральному рівні виявилися безрезультатними, президентами США стали кандидати від Республіканської партії. Щоб компенсувати моральну невдачу, К. Клівленд запропонував свою кандидатуру на виборах мера м. Буффрало і згодом - губернатора штату Нью-Йорк.

Клівленд 11 місяців працював мером і 2 роки - губернатором штату (до 6 січня 1885 р.). На посаді губернатора Г. Клівленд виявився здатним адміністратором, незалежним від партійних пристрастей. Коло його обов'язків було досить широким. Доводилося стежити за дотриманням конституції штату, керувати міліцією, контролювати, використовуючи право вето, діяльність законодавчих зборів, стежити за ощадливою витратою бюджетних засобів.

За кілька місяців до закінчення терміну губернаторства з'їзд Демократичної партії висунув Клівленда кандидатом у президенти. Одержавши на дев'ять 3 невеликим відсотків голосів більше, ніж представник Республіканської партії, він, уперше після Громадянської війни, став президентом-демократом, і 4 березня 1885 р. переїхав до Білого дому. Його супроводжувала молодша сестра Роуз, якій до одруження Г. Клівленда довелося виконувати обов'язки першої леді.

у 1884 р. Демократична партія запропонувала його кандидатом на пост президента і перемогла незначною більшістю голосів. У період першого президентства Г. Клівленда (1885-1889 рр.) була спроба відмовитися від spoil system (зміни всіх чиновників після виборів Президента); покладено межу надмірному зростанню пенсій. Клівленду було 48 років, коли він 4 березня 1885 зайняв пост президента. Г. Клівленд був єдиним президентом від Демократичної партії, що вибирався між 1860 і 1912 роками - під час повного панування республіканців.

У 1888 р. Демократична партія висунула Г. Клівленда на другий термін. Проте перемогу одержав республіканець Б. Гаррісон, який набрав понад 58\% голосів вибірників. Закінчивши службу, екс-президент зі своєю дружиною залишив 4 березня 1889 р. Білий дім, повернуся до Нью-Йорка і відновив адвокатську практику [6, с.9].

Після розчарування 1888 р. Клівленд спочатку вирішив цілком сконцентруватися на своїх фрінансових інтеpecax. За підтримки фрінансистів працював на УоллСтриті. Але ставлення до політики Гаррісона щодня підсилювала його переконаність у тім, що сам він набагато більше підходить для посади президента. Нарешті він зважився виставити свою кандидатуру, щоб врятувати націю від республіканської безгосподарності і ко- рупції, а також від срібної валюти. Він навчився на помилках останніх виборів, через те, що цього разу промовами, листами і газетною кампанією ретельно заробляв собі підтримку різних фракцій партії. Завдяки концентрованим акціям своєї передвиборної кампанії він вже в першому турі конвенту в Чікаго в 1892 р. був обраний кандидатом. Клівленд сприйняв висування як особисту спокуту. Щоб завершити тріумф, був, нарешті, готовий вести передвиборну боротьбу. Він обмежився декількома промовами, проте писав численні відкриті листи. Спритно уникав теми срібла, про яку в партії існували різні думки, і на перший план ставив тариф.

Керівництво Демократичної партії, ознайомившись 3 запропонованим Клівлендом курсом розвитку країни, особливо у валютно-фрінансовій сфрері, вважало за доцільне знову висунути його кандидатом у президенти у 1892 р. на з'їзді в м. Чікаго.

Одержавши 62,4\% голосів вибірників і залишивши Б. Гаррісона на другому місці, Клівленд став двадцять четвертим керівником країни i, переїхавши в Білий дім, розпочав виконувати 4 березня 1893 р. обов'язки. Цей рік був затьмарений економічною кризою, що почалася через непродуману митну і валютно-фрінансову політику попереднього президента США.

Клівленд здобув блискучу перемогу, але його другий термін був менш успішним, ніж цього очікували. Він був затьмарений найбільшою економічною кризою попередньої американської історії. У період з 1893 по 1897 р. закрилися 600 банків і більш 15000 підприємств збанкрутували. Безробіття зросло до 20\%. Особливо постраждали Південь і Захід. У результаті швидкого падіння цін на сільськогосподарські продукти фермери усе глибше влазили в борги і втратили власність.

Для ліквідації наслідків кризи або хоча б зменшення його впливу на економіку країни Клівленду довелося терміново приймати низку важливих рішень. Одним 3 них стало скасування, незважаючи на протести в Конгресі, прийнятого раніше закону про широкі закупівлі срібла для карбування монет.

За твердженням президента, використання у грошових операціях більш дешевих, ніж золоті, срібних доларів знецінює національну валюту і перешкоджає необхідному для розвитку економіки і міжнародної торгівлі поповненню золотого запасу країни.

Вважаючи, що проблема митних податків стала однією з причин кризи 1893 р., усі присвячені тарифам нові закони він підписувати відмовлявся, але вето не накладав. Протистояння з Конгресом зменшило популярність президента, через так званий "Пульманівський страйк" $1894 \mathrm{p}$

28 жовтня 1886 р. президент очолив церемонію відкриття в Нью-Йорку подарованою Францією Статуї Свободи.

1 травня 1893 р. урочисто відкрив у Чікаго Всесвітню виставку, присвячену 400-річчю подвигу Х. Колумба.

Демократичний з'їзд у 1888 р. знову висунув кандидатуру Клівленда, але не підтримав законопроект Міллса. Клівленд програв битву за Білий дім Б. Гаррісону, хоча і отримав підтримку значної кількості виборців. Клівленд став кандидатом у президенти в першому турі на партійному з'їзді у Чікаго у 1892 р. Здійснюючи кампанію на партійній платформі, яка обіцяла перегляд тарифів, він легко переміг Гаррісона. На посаді президента прославився своїм прагненням покласти кінець "патерналізму", відмовляючи штатам у фінансовій підтримці і навіть ветеранах війни - у виплаті пенсій. Клівленд був президентом, що частіше своїх попередників накладав вето на законопроекти. Під час свого першого терміну президентства здійснював політику обмеження 
державних витрат і зниження протекціоністських тарифів. В зовнішній політиці він дотримувався курсу Вашингтона, Джефферсона та Монро, тобто політики нейтралітету. Клівленду доводилося часто протистояти Сенатові, контрольованому республіканцями.

У 1892 р. Г. Клівленд здобув перемогу в президентських виборах. Основні напрямки його політики зводилися до зниження тарифів, зниженню податків і підтримці золотого стандарту. Під час другого терміну Клівленда було створено, 4 січня 1896, штат Юта. Клівленд був єдиним президентом від Демократичної партії, що вибирався між 1860 і 1912 рр. - під час повного панування республіканців. Незважаючи на ворожість до сильного уряду, він розумів роль президента занадто слабкою і намагався зменшити нерівність між виконавчою владою і Конгресом. У принциповому конфлікті із сенатом домігся, щоб закон про перебування в посаді, що давав Конгресові право контролю на звільнення чиновників президентом, був скасований у березні 1887 р. Г. Клівленд виявляв ініціативу, щоб досягти політичних цілей. За час перебування на посаді президента 304 рази ветував законопроекти.

Основні досягнення для держави. Головними досягненнями Клівленда-президента вважають успішне продовження реформи держслужби, широке використання раціональних митних тарифів і стабілізацію національної валюти. Клівленд в зовнішній політиці, як і раніш, відкидав експансію і тому не ратифікував підготовлений попереднім президентом договір про анексії Гавайських островів і дотримував строгого нейтралітету у відносинах з Кубою, де розгорілося повстання проти іспанського панування.

Відстоюючи доктрину Монро про невтручання європейських держав у справи США, Клівленд допоміг врегулювати Венесуельську кризу, яка виникла з приводу кордону з британською колонією Гвіаною. Ще одним доказом мудрої зовнішньополітичної діяльності Г. Клівленда стала угода з Англією і Німеччиною про архіпелаг Самоа, що гарантують його автономію під протекторатом трьох держав. Наклав понад 100 вето на законопроекти, прийняті в ході першої сесії Конгресу. Багато з цих законопроектів стосувалися пенсій і зазвичай автоматично приймалися Конгресом. Найбільш жорсткою була позиція Клівленда 3 питання про зниження тарифів, завищення яких він вважав поступкою груповим інтересам і основним джерелом небезпечного переповнення скарбниці [8, с.5].

Двома великими фінансово-політичними питаннями його президентства були срібний стандарт і питання мита. Економіка страждала від гострого недоліку грошей, тому поряд із золотим доларом був уведений срібний, вартістю на 20 відсотків нижче. Наслідком цього стало приватне накопичення золотих доларів і постійне зменшення золотого резерву союзу. Як захід проти підриву валюти Клівленд зажадав скасування срібного долара, але зазнав невдачі в Конгресі. Могутні сили, особливо 3 аграрного Півдня і Середнього Заходу США, бажали інфляційної грошової політики за допомогою повного дозволу срібного долара, щоб усунути хронічний недолік грошей і надборги у фермерському господарстві.

В зовнішній політиці у 1887 р. США отримали морські права на гавайський Перл-Харбор. 3 ініціативи держсекретаря Блейна в 1889 р. був скликаний Панамериканський конгрес - для обговорення американських перспектив у Латинській Америці. Національні лідери, однак, виявляли нерішучість. Так, розбіжності в Конгресі перешкодили анексії Санто-Домінго і створенню морських баз на Кубі, Гаїті, Венесуелі, США втратили ініціативу в спорудженні каналу на
Панамському перешийку, яке розпочала Франція. Гровер Клівленд виявляв себе переконаним супротивником політики експансіонізму.

Основні невдачі періоду президентства через те, що відмовився звільнити державних службовців з числа республіканців, а призначенням двох жителів півдня членами кабінету викликав неприязнь багатьох республіканців. Наказавши у 1887 р. військовому відомству повернути захоплені бойові прапори конфедератів південним штатам, ще більш налаштував проти себе "сіверян". Невдала митна реформа, внаслідок опору сенату.

Отримав визнання за позицію з питання про зниження тарифів, завищення яких він вважав поступкою груповим інтересам і основним джерелом небезпечного переповнення скарбниці. Ощадливе управління привело фінанси США в блискучий стан. Президент і його адміністрація допомагали здійснювати низку загальнонаціональних заходів. У тому числі входження в Союз семи нових штатів і проведення двох так званих земельних перегонів, які мали значення для розвитку фермерства і сільського господарства. У цих перегонах десятки тисяч американців із усіх районів країни поїхали до штату Оклахома, щоб встигнути одержати там в особисту власність ділянки землі, які були попередньо викуплені урядом в індіанських племен.

Він домігся скасування невиправдано високих пенсійних виплат ветеранам Громадянської війни і сформував федеральну комісію з боротьби з масштабними зловживаннями і розбазарюванням коштів у залізничному бізнесі. Завдяки цьому дохідна частина бюджету перевищила до кінця першого терміну його президентства видаткову складову на 100 млн доларів.

Президент активно продовжував розпочату декілька років назад реформу державної служби. Приділяючи увагу удосконалюванню судової системи, він здійснив масштабні кадрові зміни в окружних та Верховному судах США.

Найважливішою подією став підтриманий президентом закон про нові права на землю індіанців: виконавча влада одержала можливість розподіляти общинну територію резервацій між усіма людьми племені з наступною передачею ділянок у власність землевласників і наданням їм громадянства США.

Був критикований за відмову звільнити державних службовців з числа республіканців, викликав критику республіканців призначенням двох мешканців півдня членами кабінету; наказав у 1887 р. військовому відомству повернути захоплені бойові прапори конфедератів південним штатам, налаштував проти себе мешканців Півночі.

"Він був надто великим президентом, людиною, яка не лише правильно цінувала гідність його вищої посади, але і додав їй гідності. Контраст між президентом Клівлендом і нинішнім мешканцем Білого дому екстраординарний; це - контраст між архангелом і Відсутньою ланкою. Клівленд був усім, чим повинен бути президент; Рузвельт - усім, чим не повинен бути президент - він покриває всю землю" (Автобіографія Марка Твена, Том 3)

Громадське життя після президентства. Він повернувся до Нью-Йорка і відновив свою адвокатську практику, але після прийняття протекціоністського закону Мак-Кінлі про тарифи в 1890 р. почався загальнонаціональний рух за повторне висунення Клівленда.

Найвідомішими промовами були: Перша інавгураційна промова 4 березня 1885 р.; Друга інавгураційна промова 4 березня 1893 р.; 20 липня 1895 р. президент в промові закликав Великобританію до ухвалення арбітражного рішення за американської участі. Він 
обґрунтував свою вимогу тим, що "Сполучені Штати сьогодні практично незалежні на континенті і що їхня воля є законом".

Звернення до Конгресу США 8 січня 1894 р "Пенсійні виплати ветеранам Громадянської війни"; звернення до Конгресу США"Реформа державної служби"; промова щодо Закону про нові права на землю індіанців;

Промова на відкритті монумента Статуї Свободи в Нью-Йоркському порту у 1886 р.

Приватне життя. Будучи холостяком, Г. Клівленд одружився лише у віці 49 років, 2 червня 1886 р. Г. Клівленд був єдиним в історії президентом США, який одружився в Білому Домі (в день весілля Клівленду було 49 років, його обраниці - 21, причому наречений знав наречену з пелюшок). Під час своєї першої виборчої кампанії Клівленда переслідували чутки про батьківство позашлюбної дитини. Після обрання холостяк Клівленд, який не зміг впоратися з величезним господарством Білого дому, одружився з Френсіс Фолсом (1886); він був другим (після Джона Тайлера) президентом, хто одружився на посаді, і єдиним, хто мав весілля у Білому домі. Першою леді стала Френсіс Клара Фолсом, яка знала чоловіка з раннього дитинства. Ї̈̈ батько, адвокат Оскар Фолсом, чимало років дружив з майбутнім президентом. Обмежений вільний час проводив із друзями за покером, на полюванні і риболовлі.

Після інавгурації президента Мак-Кінлі Клівленд у приватному житті мешкав зі своєю родиною в Прінстоні, в якому як попечитель університету підтримував тісний контакт із Вудро Вільсоном, майбутнім президентом. Але як голова союзної організації страхових компаній і насамперед як публіцист Клівленд продовжував брати участь у громадському житті. Будинок був куплений у 1896 р. і названий на честь друга, що допомагав у покупці, Вестлендом. У ньому Гровер і Френсіс виховували своїх дітей, пережили смерть своєї першої дочки Рут і тішилися народженню двох синів. У вільний час пенсіонер займався реконструкцією будинку і журналістикою, зустрічався з одно партійцями, із Теодором Рузвельтом. Був членом ради з опіки Прінстонського університету і Національної асоціації. Клівленд помер від серцевої недостатності 24 червня 1908 р. і був похований на цвинтарі у Прінстоні. Його вдова кілька років продовжувала жити в маєтку і потім у віці 49 років удруге вийшла заміж за Т. Престогона, професора археології Прінстонского університету. Померла Френсіс 29 жовтня 1947 р. у місті Балтіморі.

Відомими висловлюваннями є: "Що б ти не робив говори правду. Проблема не в теорії, а в обставинах. Ніхто ніколи не потрапив на шибеницю за порушення духу закону. Народний уряд для досягнення успіху має покладатися на розум, мораль, справедливість і зацікавленість народу". У 1893 р. "час уже відкинути колишні канони заступницького піклування з боку уряду і засвоїти новий стереотип відносин: це народ повинен радісно і віддано надавати підтримку урядові, а аж ніяк не навпаки". На зміну позиції "пасивній бездіяльності" прийшла позиція "активного панування". Гасло Державна служба - державна відповідальність стало лейтмотивом політичної кар'єри. Найкращі результати роботи уряду, у якому є дещиця роботи кожного громадянина, значною мірою залежать від належного обмеження чисто партійної упертості і діяльності і правильного почуття часу, коли розпалення партійних пристрастей потрібно об'єднати 3 патріотизмом громадян. "Кожен громадянин доручає країні невтомно контролювати своїх чиновників, справедливо і правдиво оцінювати їхню відданість своїй справі і тій користі, що вони приносять.
У такий спосіб народна воля впливає на всю систему нашого громадянського суспільства - муніципальну, штату і федеральну; і це - ціна нашої свободи і нашої натхненної віри в республіку".

Геніальність наших інститутів, потреби наших людей у їхньому повсякденному житті й увага, яку потрібно приділяти заселенню нашої території і розробці ії ресурсів, диктують необхідність ретельно уникати будь-якого відхилення від тієї зовнішньої політики, що виправдала наша історія, традиції і процвітання нашої республіки.

Висновки. Спеціального аналізу вимагають такі прояви, як особливі повноваження президента в умовах надзвичайного стану, взаємини глави держави з різними суспільно-політичним групами і засобами масової інформації, стилі політичної поведінки президентів і норми їхньої відповідальності за свої дії, розгляд оптимальних варіантів організації роботи апарату президента, процедури передачі владних повноважень від одного президента до іншого, професійних і особистісних характеристик президентів. Проблематика, пов'язана 3 аналізом інституту президентства, велика і різноманітна, має потребу в подальших дослідженнях.

Незважаючи на те, що статус глави держави є універсальним, функціонування цілого ряду моделей "президентства виявляє залежність від різних політичних режимів і різних систем державного правління. За авторитарних режимів президентська влада часто здобуває риси режиму особистої влади. У демократичних країнах глава держави служить одним з ведучих гарантів непорушності конституційних основ політичної системи.

Не менш важливо і те, що кожному типі державного правління відповідає тип президентства з його особливими рольовими функціями. За умов президентської республіки президент, сполучаючи повноваження глави держави і глави уряду, має бути ефективним політичним лідером, що безпосередньо керує урядовою політикою. За напівпрезидентської республіки президент, не будучи главою уряду, нерідко виступає у відповідальній ролі арбітра у відносинах між кабінетом міністрів і парламентом. Парламентарна республіка наділяє президента статусом "першого громадянина", що має високий моральний авторитет і представляє свою країну в офріційних актах державної влади. Однак за будь-яких моделей президентства глава держави несе відповідальність за збереження законності, злагоди і стабільності в суспільстві.

Процес створення правлячої команди складається 3 внутрішніх та зовнішніх аспектів. Внутрішні полягають у логіці передвиборних угод з політичними силами всередині передвиборчої кампанії, а зовнішні - у міркуваннях щодо розширення соціальної бази підтримки правлячої команди. Отже, при формуванні правлячого кабінету лідер, який досяг на виборах або в інший спосіб такого права мусить керуватися при доборі кадрів своєї команди професійними, політичними та психологічними критеріями.

Загрозою політичній модернізації $€$ неадекватність фрункціонування демократичних інститутів і механізмів.

\footnotetext{
Список використаних джерел: 1885.

1. King, "Life and public services of Grover Cleveland". - Нью-Йорк,

2. Parker, "The writings and speeches of Grover C." - Нью-Йорк, 1892.

3. Nevins, Allan. Grover Cleveland: A Study in Courage (1932) Pulitzer Prize-winning biography.

4. Гровер Кливленд - Инаугурационная речь, 1885. Grover Cleveland - Inaugural Address, 1885

5. Инаугурационные речи Президентов США. Харьков: Folio, 2009. - C.153-157.

6. Осадчук І. Ю. Порівняльний аналіз президенціалізації систем правління у Білорусі та Казахстану : автореф. дис. ... канд. політ. наук :
} 
23.00.02 / Осадчук Ігор Юрійович ; Львів. нац. ун-т ім. Івана Франка. Львів, 2014. -20 с.

7. Парно Л. Д. Інституційні чинники ефективності функціонування уряду за напівпрезидентської республіки (на прикладі Франції) : автореф. дис. ... канд. політ. наук : 23.00.02 / Парно Леся Дмитрівна ; Київ. нац. ун-т ім. Тараса Шевченка. - Київ, 2015. - 21 с.
8. Сидорчук О. В. Вплив напівпрезидентської форми правління на демократичну консолідацію постсоціалістичних політичних режимів (на прикладі Польщі, Росії та України) : автореф. дис. ... канд. політ. наук : 23.00.02 / Сидорчук Олексій Володимирович; НАН України, ІН-Т політ. і етнонац. досліджень ім. І. Ф. Кураса. - Київ, 2016. - 15 с.

Надійшла до редколегії 26.02.19

О. І. Ткач

\section{INSTITUTE OF PRESIDENCY AS A CONCEPTUAL POWER IN DEMOCRATIC POLITICAL SYSTEMS}

Formulation of the problem: The features of model of presidencialism in modern terms, possibility of application of presidencialism in democracy are analysed in the article. Analis of concept: politics, decision of political conflicts. The political factors of political strategies of presidencialism are considered, of institute of the president, as subject of conceptual power and democratic political system, as its object is investigated. It is shown, that the real model of political system contains oligarchic and antiolygarchic components, each of which can become prevailing.

Purpose of the research: The purpose of the article is to carry out a theoretical and methodological analysis of the essence of the presidency as a subject of conceptual power in democratic political systems, to identify the structure of conceptual power, its role and place in the political system of society, to identify trends and to analyze the role of the processes of oligarchization in the functioning of democratic political systems, to uncover conceptual functions of the institution of presidency in western democratic political systems. The conceptual management of political system, preservation its of democratic definiteness, is a major task of presidential power. Using theoretical models $D$. Easton, E. Sedov, theory of needs A. Maslow and theory of social mobility of P. Sorokin has allowed to reveal static and dynamic parameters of political system, which optimization enables to support evolutionary character of political development.There are several alternative concepts of democracy. At the same time, one of them is legally codified and reigns. That is why political power is usually forced to act in an anti-democratic way on an alternative concept. Institutions of state power, thanks to sustainability, mobility and resource intensiveness, can support and even impose those norms and goals that are not entirely in the interests of society as integrity, or vice versa - the interests of individual, usually the most active individuals and social groups are not taken into account and even sacrificed in general. There is a significant imbalance of interests that threatens the existence of a democratic social system. Consequently, the task arises to develop objective indicators, which should be guided by the head of state, in order to assess the favorable or unfavorable tendencies in the political system. The purpose of the article and the task.

Research methods: The following research methods were used to address the issues set in the article: general scientific methods - descriptive, hermeneutic-political, systemic, structural-functional, comparative, institutional-comparative; general logical methods - empirical, statistical, prognostic modeling and analysis; special methods of political science. The preference was given to the method of political-system analysis, by which the common and distinctive characteristics of the basic components of soft power strategies were identified, reflecting existing political, public, information and other challenges and global development. For empirical research, the factual basis was used, which was compiled by an expert survey of Ukrainian specialists-political scientists. Practical and systematic methods were used to analyze the system of relations from four perspectives: influence presidents power. Functional and general historiographical methods were also used. Methods of analysis and synthesis allowed exploring the features. In order to implement these methods, such methodological techniques as analogy, comparison, generalization and extrapolation were used. The method for analyzing the situation (studying documents, comparing, etc.) was used to study international and political processes in the USA, exploratory methods (in particular, content analysis) for the analysis of high-level documents and speeches, which in turn helped identify and outline the trends in foreign policy of the countries of the region.

Conclusions. The experience of western (Western, liberal-democratic) political systems suggests that the function of supporting the democratic model of the political system is the responsibility of the president. In this case, the president plays the role of either the head of the executive (political manager of the higher rank), or the formal head of state, or these functions combine. In the context of the political crisis, the president takes steps to preserve the democratic system of society. The complex of these activities includes the function of supporting the democratic nature of the political system

Key words: politics, model of politics, political consolidation.

О. И. Ткач

\section{ИНСТИТУТ ПРЕЗИДЕНТСТВА КАК СУБЬЕКТ КОНЦЕПТУАЛЬНОЙ ВЛАСТИ} В ДЕМОКРАТИЧЕСКИХ ПОЛИТИЧЕСКИХ СИСТЕМАХ

В статье анализируются особенности модели института президента в США в современных условиях, возможности применения президенциализма в розвитии демократии. Проанализироны понятия: демократическая политика президента, решение политических конфликтов. Рассмотрены политические факторы политических стратегий института. Концептуальная власть является специфической разновидностью политической власти, которая заключается в осуществлении политического руководства, определении стратегических приоритетов политического развития и параметров функционирования политической системы.

Ключевые слова: политика, политическая консолидация, концептуальная власть, институт президентства, институт президента, концепция государственного порядка, демократическая политическая система, антиолигархические концепции. 